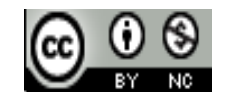

Jurnal Pendidikan Matematika Indonesia is licensed under

A Creative Commons Attribution-Non Commercial 4.0 International License

\title{
IDENTIFIKASI KeSAlahan MAHASISWA DAlam MENYEleSAIKAN SoAL Kalkulus PeUbah BAnYaK Berdasarkan TAKSONOMi Solo
}

\author{
Fadrik Adi Fahrudin \\ Program Studi Tadris Matematika, FTK UIN Mataram \\ E-mail:fadrik@uinmataram.ac.id
}

\begin{abstract}
Abstrak. Penelitian ini mengkaji tentang identifikasi letak, penyebab dan kategori kesalahan yang dilakukan mahasiswa ketika mengerjakan soal Kalkulus Peubah Banyak dengan menggunakan pendekatan kualitatif berjenis penelitian deskiptif terhadap mahasiswa kelas III-A Program Studi Tadris Matematika, UIN Mataram. Subyek penelitian dan wawancara terdiri dari 2 mahasiswa berkemampuan rendah, 2 mahasiswa berkemampuan sedang dan 2 mahasiswa berkemampuan tinggi. Identifikasi kesalahan mahasiswa dilakukan menggunakan Taksonomi SOLO (The Structure of the Observed Learning Outcome). Hasil penelitian menunjukkan bahwa kesalahan yang dilakukan mahasiswa berada dalam kategori: 1) kesalahan konsep, dikarenakan mahasiswa melakukan kesalahan dalam menentukan batas integral dan kesalahan dalam mensubstitusikan batas integral, 2) kesalahan operasi, mahasiswa melakukan kesalahan dalam mengoperasikan bilangan ke fungsi integral, 3) kesalahan faktual, mahasiswa tidak bisa menjawab karena tidak memiliki kemampuan dalam memahami soal, dan 4) kesalahan prosedur, mahasiswa melakukan kesalahan dalam sistematika penyelesaian.
\end{abstract}

Kata Kunci: Identifikasi Kesalahan, Kalkulus Peubah Banyak, Taksonomi SOLO

\section{PENDAHULUAN}

Pendidikan mempunyai tugas yang cukup berat, yaitu menyiapkan sumber daya manusia untuk menunjang proses pembangunan yang terus berjalan. Semangat pembangunan selalu diupayakan seiring dengan tuntutan zaman. Perkembangan zaman selalu memunculkan tantangantantangan yang sebagian diantaranya tidak dapat diprediksi sebelumnya. Hal ini berakibat munculnya hal-hal baru, termasuk problematika yang menyertainya dalam dunia pendidikan. Setidaknya, pada saat ini terdapat empat masalah pokok pendidikan yang telah menjadi kesepakatan nasional, yaitu: masalah pemerataan pendidikan, mutu pendidikan, efisiensi pendidikan dan relevansi pendidikan.

Pasal 1 Undang-Undang Guru dan Dosen yang berbunyi: "Dosen adalah pendidik profesional dan ilmuwan dengan tugas utama mentrasformasikan, mengembangkan, dan menyebarluaskan ilmu pengetahuan, teknologi, dan seni melalui pendidikan, penelitian, dan pengabdian kepada masyarakat", menuntut setiap guru dan dosen mempunyai kompetensi untuk menjalankan tugas utamanya tersebut pada level/ jenjang pendidikan yang diajar. Pengajaran pada dasarnya adalah upaya pemanfaatan atau penggunaan ilmu yang didapat untuk meningkatkan keterampilan, bakat dan potensi yang dimiliki seseorang untuk menghadapi kemajuan zaman dan bekal seseorang bersaing dalam kehidupan global. Pengertian ini juga mengandung makna bahwa seorang dosen dapat berperan sebagai organisator kegiatan belajar mahasiswa. Dosen tidak hanya menjadi fasilitator, tetapi juga evaluator proses pengajaran yang dilakukan, termasuk melakukan diagnosis terhadap kesulitan dan kebutuhan mahasiswa. Hal ini berarti bahwa evaluasi yang dimaksud tidak hanya menggali tentang mampu atau tidaknya mahasiswa melalui hasil tes yang diberikan, tetapi juga untuk mengkaji sekaligus menindaklanjuti kesalahan mahasiswa dalam merespon setiap permasalahan yang disajikan. Kenyataan di lapangan menunjukkan bahwa pembelajaran matematika di Perguruan Tinggi cenderung menekankan keterampilan mengerjakan soal, sedangkan penanaman konsepnya hanya diberikan dalam waktu yang singkat, sehingga mahasiswa sering melakukan kesalahan mengerjakan soal.

Pembelajaran matematika dikonstruksi dari bahan/materi yang bersifat kongkrit menuju abstrak, dari yang mudah menuju yang sulit, berawal dari bilangan bulat ke bilangan pecahan, dari bilangan riil ke bilangan kompleks, dari penjumlahan dan perkalian ke diferensial dan integral, dan secara umum menuju matematika yang lebih tinggi. Dalam melakukan kegiatan belajar dosen tidak selamanya berhasil menanamkan konsep materi sesuai dengan kompetensi yang ingin dicapai, tapi terkadang juga mengalami hambatanhambatan yang mengakibatkan kegagalan belajar. Hambatan-hambatan belajar matematika tersebut dapat dikatakan sebagai suatu kondisi yang ditandai dengan 


\section{- - - Jurnal Pendidikan Matematika Indonesia \\ Volum 3 Nomor 1 bulan Maret 2018. Page 7-14 \\ p-ISSN: 2477-5967 e-ISSN: 2477-8443}

adanya kesalahan/kesulitan yang terjadi ketika proses penyampaian materi maupun evaluasi berlangsung.

Faktor-faktor yang mempengaruhi hambatan dalam belajar dapat terjadi karena faktor intern dan faktor ekstern mahasiswa. Ketidakmampuan dosen dalam menciptakan suasana belajar matematika yang menarik, serta belum maksimalnya peran mahasiswa secara aktif dapat mengakibatkan pembelajaran menjadi tidak efektif, semangat dan motivasi belajar mahasiswa juga menjadi berkurang, yang berakibat pada capaian prestasi belajar mahasiswa menjadi rendah. Namun hal ini belum sepenuhnya disadari oleh setiap dosen, sehingga letak dan penyebab kesulitan belajar yang dialami mahasiswa juga belum sepenuhnya teridentifikasi. Untuk membantu mahasiswa dalam penanaman konsep matematika agar dapat mengerjakan soal-soal matematika, maka seorang dosen perlu melakukan identifikasi kesalahan mahasiswa dalam mengerjakan soal-soal yang diberikan. Salah satu alternatif identifikasi tersebut adalah menggunakan taksonomi SOLO (The Structure of the Observed Learning Outcome) sebagai suatu alat evaluasi tentang kualitas respon mahasiswa terhadap suatu tugas. Taksonomi SOLO dikembangkan oleh Bigg dan Collins pada tahun 1982 dengan tujuan mengelompokkan tingkat kemampuan peserta didik pada lima level berbeda dan bersifat hierarkhis, yaitu:

a. Level 0: prastruktural (pre-structural);

b. Level 1: unistruktural (uni-structural);

c. Level 2: multistruktural (multy-structural);

d. Level 3: relasional (relational); dan

e. Level 4: extended abstract.

Menurut Bigg dan Collins, analisa kesalahan dengan menggunakan Taksonomi SOLO untuk mengetahui respon peserta didik/mahasiswa mempunyai beberapa kelebihan, yaitu:

a. Taksonomi SOLO merupakan alat yang mudah dan sederhana untuk menentukan level respon mahasiswa terhadap pertanyaan matematika;

b. Taksonomi SOLO merupakan alat yang mudah dan sederhana untuk pengkategorian kesalahan dalam menyelesaikan soal atau pertanyaan;

c. Taksonomi SOLO merupakan alat yang mudah dan sederhana untuk menyusun dan menentukan tingkat kesulitan atau kompleksitas suatu soal matematika; dan

d. Taksonomi SOLO memberikan peluang mahasiswa untuk selalu berpikir alternatif.

Berdasarkan hasil wawancara antara peneliti dengan mahasiswa semester 3 Program Studi Tadris Matematika UIN Mataram, diperoleh kesimpulan bahwa sebagian besar mahasiswa menyatakan mata kuliah Kalkulus Peubah Banyak adalah mata kuliah yang sulit. Hal ini sesuai dengan hasil Ujian Akhir Semester (UAS) dimana masih banyak ditemukan kesalahan yang dilakukan mahasiswa, sehingga menyebabkan rendahnya skor/nilai yang diperoleh.

Berdasarkan fenomena tersebut di atas, peneliti tertarik untuk melakukan kajian "Identifikasi Kesalahan Mahasiswa dalam Menyelesaikan Soal Kalkulus Peubah Banyak Program Studi Tadris Matematika UIN Mataram". Dengan demikian, perlu adanya suatu model penilaian berbasis taksonomi SOLO pada materi Kalkulus Peubah Banyak dengan memberikan kesempatan kepada mahasiswa untuk berpikir alternatif. Pemilihan materi dilakukan berdasarkan data di lapangan yang menyatakan bahwa Kalkulus Peubah Banyak termasuk mata kuliah yang sulit. Oleh karena itu peneliti bermaksud mengembangkan model penilaian berbasis taksonomi SOLO pada Kalkulus Peubah Banyak. Penelitian ini dilakukan dengan maksud untuk memperoleh gambaran mengenai model evaluasi Kalkulus Peubah Banyak menggunakan taksonomi SOLO, memahami proses implementasi model penilaian berbasis taksonomi SOLO pada Kalkulus Peubah Banyak dan menganalisis karakteristik respon mahasiswa semester 3 Program Studi Tadris Matematika dalam menyelesaikan soal berdasarkan taksonomi SOLO.

\section{METODE PENELITIAN}

Pendekatan yang dilakukan dalam penelitian ini adalah kualitatif dengan jenis penelitian deskriptif. Peneliti bermaksud untuk mendeskripsikan secara detail faktorfaktor penyebab terjadinya kesalahan yang dilakukan mahasiswa dalam menyelesaikan soal-soal Kalkulus Peubah Banyak. Pengamatan dilakukan pada hasil kerja siswa dan wawancara dengan siswa yang mewakili tiap kategori kesalahan. Penelitian ini dilakukan di kelas III-A Program Studi Matematika, UIN Mataram. Data yang telah diperoleh kemudian dianalisis dengan cara reduksi data, penyajian data dan selanjutnya diverifikasi sebagai langkah untuk menarik kesimpulan.

Penelitian ini diawali dengan mengkaji masalah yang dihadapi oleh mahasiswa Program Studi Tadris Matematika tentang materi Kalkulus Peubah Banyak. Pengkajian ini dilakukan melalui proses observasi saat proses perkuliahan berlangsung. Setelah masalah ditemukan, kemudian peneliti melakukan kajian teori-teori yang berkaitan dengan masalah yang ditemukan tersebut. Pengkajian teori ini bertujuan untuk mengetahui kebenaran dari suatu permasalahan berdasarkan teori-teori yang ada menurut para ilmuan. Dari hasil observasi dan pengkajian teori muncul permasalahan dalam penelitian ini. Langkah selanjutnya yang peneliti lakukan adalah menentukan subyek dalam penelitian yang dapat memberikan informasi dari masalah yang diteliti. Setelah mendapatkan subyek penelitan, peneliti selanjutnya mengumpulkan data dengan menggunakan tes dan wawancara.

Pemberian tes bertujuan untuk memperoleh data dan bahan pengamatan mengenai kesalahan mahasiswa dalam menyelesaikan soal-soal Kalkulus Peubah Banyak. Teknik wawancara dilakukan dengan tujuan untuk mengetahui dan menangkap secara langsung seluruh informasi dari subyek penelitian. Wawancara dilakukan terhadap mahasiswa yang menjadi subyek penelitian yang terdiri dari 2 mahasiswa dari kelompok atas, 2 mahasiswa dari kelompok sedang, dan 2 mahasiswa dari kelompok bawah yang masing-masing memiliki kesalahan terbanyak dari kelompoknya. Wawancara dilakukan dengan perekaman pada tape recorder, sehingga hasil wawancara menunjukkan keabsahan dan dapat teroganisir dengan baik untuk analisis selanjutnya. 


\section{- - - Jurnal Pendidikan Matematika Indonesia \\ Volum 3 Nomor 1 bulan Maret 2018. Page 7-14 \\ p-ISSN: 2477-5967 e-ISSN: 2477-8443}

Data yang telah didapatkan selanjutnya dilakukan proses analisis. Analisis adalah suatu usaha untuk mengurai suatu masalah atau fokus kajian menjadi bagian-bagian (decomposition), sehingga susunan atau tatanan bentuk suatu yang diurai itu tampak dengan jelas dan karenanya bisa secara lebih terang ditangkap maknanya atau lebih jernih dimengerti duduk perkaranya. Menurut Bogdan \& Biklen (1982), analisis data kualitatif adalah upaya yang dilakukan dengan jalan bekerja dengan data, mengorganisasikan data, memilah-milahnya menjadi satuan yang dapat dikelola, mensintesiskannya, mencari dan menemukan pola, menemukan apa yang penting dan apa yang dipelajari, dan memutuskan apa yang dapat diceritakan kepada orang lain.

Analisis data kualitatif yang peneliti gunakan pada penelitian ini melalui tiga proses, yaitu reduksi data (data reduction), penyajian data (display data) dan penarikan kesimpulan.

\section{Reduksi data}

Reduksi data diartikan sebagai proses pemilihan, pemusatan perhatian pada penyederhanaan, pengabstrakan, dan transformasi data mentah yang muncul dari catatancatatan tertulis di lapangan. Jadi, proses analisis data dalam penelitian ini dimulai dengan mengoreksi hasil tes mahasiswa, yang kemudian akan dirangking untuk menentukan mahasiswa yang akan dijadikan sebagai subyek penelitian. Hasil pekerjaan mahasiswa tersebut merupakan data mentah yang akan ditransformasikan pada catatan sebagai bahan untuk wawancara dan langkah terakhir hasil wawancara tersebut, disederhanakan menjadi susunan bahasa yang baik dan rapi, kemudian ditransformasikan ke dalam catatan.

\section{Display data (penyajian data)}

Penyajian data diarahkan agar data hasil reduksi terorganisasikan, tersusun dalam pola hubungan, sehingga makin mudah dipahami. Penyajian data dapat dilakukan dalam bentuk uraian naratif, bagan, hubungan antar kategori, diagram alur (flow chart), dan lain sejenisnya. Penyajian data dalam bentuk-bentuk tersebut akan memudahkan peneliti memahami apa yang terjadi dan merencanakan kerja penelitian selanjutnya. Pada langkah ini, peneliti berusaha menyusun data yang relevan sehingga menjadi informasi yang dapat disimpulkan dan memiliki makna tertentu. Prosesnya dapat dilakukan dengan cara menyajikan hasil pekerjaan siswa yang dijadikan bahan untuk wawancara. Kemudian menyajikan hasil wawancara yang telah direkam pada tape recorder. Dari hasil penyajian data (hasil ujian akhir semester mahasiswa dan wawancara) dilakukan analisis dan membuat hubungan antar fenomena untuk memaknai apa yang sebenarnya terjadi dan apa yang perlu ditindaklanjuti untuk mencapai tujuan penelitian.

3. Verifikasi data atau penarikan kesimpulan

Langkah berikutnya dalam proses analisis data kualitatif adalah menarik kesimpulan berdasarkan temuan atau melakukan verifikasi data. Jadi penarikan kesimpulan ini adalah kegiatan menghubungkan dan menyimpulkan secara utuh, sehingga mampu menjawab pertanyaan penelitian dan tujuan penelitian. Langkah yang dapat dilakukan adalah membandingkan hasil pekerjaan mahasiswa dan hasil wawancara maka dapat ditarik kesimpulan letak dan penyebab mahasiswa melakukan kesalahan dalam menyelesaikan soal.

Setelah dilakukan analisis, peneliti menginterpretasi semua data yang ada dengan menghubungkan fakta yang ditemukan dalam penelitian dengan teori, sehingga peneliti dapat memberikan kesimpulan sebagai hasil dari penelitian.

\section{HASIL DAN PEMBAHASAN}

Hasil

Peneliti mengumpulkan data tentang kesalahan-kesalahan yang dilakukan oleh mahasiswa dalam menyelesaikan soalsoal pada mata kuliah Kalkulus Peubah Banyak melalui pemberian tes dan wawancara. Langkah pertama yang dilakukan peneliti adalah memberikan tes uraian kepada seluruh mahasiswa kelas III-A sebanyak 5 butir soal. Setelah tes uraian diberikan, peneliti memberikan penilaian jawaban mahasiswa sekaligus untuk menentukan jenis-jenis kesalahan apa yang dilakukan mahasiswa dan selanjutnya mereduksi data untuk memilih 6 mahasiswa yang dijadikan subyek penelitian. Setelah subyek penelitian ditentukan, peneliti menjadikan jawaban mahasiswa sebagai bahan untuk wawancara. Wawancara yang peneliti lakukan adalah wawancara tidak terstruktur. Setelah melakukan reduksi data, langkah selanjutnya adalah menyajikan data untuk dilakukan analisis. Kemudian disimpulkan berupa data temuan sehingga dapat menjawab permasalahan dalam penelitian.

Dari hasil reduksi data, penyajian data dan verifikasi, maka peneliti menemukan data dari masing-masing subyek penelitian sebagai berikut.

1. Subyek penelitian 1 (AK, NIM. 160103002)

Pada soal nomor 1, AK tidak dapat menyelesaikan jawaban dan hanya mampu menentukan rumus turunan parsial terhadap $\mathrm{x}$ saja. Soal nomor 2, AK melakukan kesalahan operasi hitung bilangan yang berakibat salahnya seluruh jawaban yang ditulis. Soal nomor 3, AK tidak memahami pertanyaan tentang lagrange multipliers sehingga tidak mampu menjawab dengan baik. Pada soal nomor 4, AK melakukan kesalahan pada penentuan nilai batas atas integral yang berakibat terjadinya kesalahan pada seluruh jawaban di bawahnya padahal operasi yang dilakukan benar. Pada soal nomor 5, AK melakukan kesalahan, yaitu tidak runtutnya jawaban yang ditulis, yang diindikasikan sebagai hasil dari contekan.

2. Subyek penelitian 2 (MIH, NIM. 160103026)

Pada soal nomor 1, secara umum MIH sudah memahami apa yang ditanyakan serta mampu menyelesaikannya, namun pada bagian kesimpulan akhir MIH melakukan kesalahan operasi yang berakibat pada kesalahan pada jawaban akhirnya. Pada soal nomor 2, MIH tidak menguasai secara baik soal turunan berarah yang diberikan. Soal nomor 3, MIH tidak dapat menuliskan jawaban karena ketidakmampuan memahami pertanyaan lagrange multipliers. Pada soal nomor 4, MIH terindikasi melakukan contekan karena struktur jawaban tidak sistematis dan hanya benar pada saat menentukan batasan integral saja. Pada soal 
nomor 5, MIH melakukan kesalahan operasi bilangan sehingga berakibat kesalahan dalam menjawab pertanyaan.

3. Subyek penelitian 3 (NA, NIM. 160103011)

Pada soal nomor 1, NA memahami pertanyaan dan mampu merumuskan jawaban dengan baik, namun pada bagian akhir NA melakukan kesalahan operasi sehingga jawaban akhir tidak tepat. Untuk soal nomor 2, NA mampu mengerjakan dengan benar, sedangkan pada soal nomor 3 , NA kembali melakukan kesalahan hitung bilangan seperti soal nomor 1. Pada soal nomor 4, NA melakukan kesalahan ketika mensubstitusikan batas integral ke fungsi integral, dan pada soal nomor 5, NA kembali melakukan kesalahan operasi pada bagian akhir (seperti soal nomor 1 dan 3) akibat ketidaktelitian yang bersangkutan.

4. Subyek penelitian 4 (TR, NIM. 160103006)

Pada soal nomor 1, TR memahami pertanyaan dan mampu merumuskan jawaban dengan baik, namun pada bagian akhir TR melakukan kesalahan operasi sehingga jawaban akhir tidak tepat tetapi pada soal nomor 2, TR mampu menjawab pertanyaan dengan baik. Pada soal nomor 3, TR terindikasi melakukan contekan karena struktur jawaban tidak sistematis dan hanya benar pada saat menentukan menghitung taksiran nilai diferensial. Pada soal nomor 4, NA melakukan kesalahan ketika mensubstitusikan batas integral ke fungsi integral. Pada soal nomor 5, NA kembali melakukan kesalahan operasi pada bagian akhir akibat ketidaktelitian yang bersangkutan.

5. Subyek penelitian 5 (NMK, NIM. 160103012)

Pada soal nomor 1, 2, 3, dan 5, NMK mampu menjawab pertanyaan dengan baik. Namun pada soal nomor 4, NMK melakukan kesalahan operasi hitung bilangan.

6. Subyek penelitian 6 (AM, NIM. 160103030)

Pada dasarnya AM mampu memahami seluruh soal dengan baik dan menjawab pertanyan dengan benar. Namun pada soal nomor 4, AM melakukan kesalahan operasi hitung bilangan.

\section{Pembahasan}

A. Letak dan Jenis Kesalahan serta Penyebab Mahasiswa Melakukan Kesalahan.

Setelah mengidentifikasi kesalahan mahasiswa dalam menyelesaikan soal Kalkulus Peubah Banyak dengan mengacu pada hasil analisis data yang telah dilakukan, peneliti mengelompokkan letak dan jenis kesalahan tersebut berdasarkan fokus penelitian yang telah ditetapkan seperti yang disajikan pada tabel berikut.

TABEL I

REKapitulasi LETAK KeSAlaHan BERdasarkan FoKus PENELITIAN

\begin{tabular}{ccccc}
\hline \multirow{2}{*}{ No Soal } & \multicolumn{4}{c}{ Letak Kesalahan } \\
& KK & KO & KF & KP \\
\hline 1 & 1 & 3 & 0 & 0 \\
2 & 1 & 1 & 0 & 0 \\
3 & 0 & 1 & 2 & 1 \\
4 & 3 & 2 & 0 & 1 \\
5 & 0 & 3 & 0 & 1 \\
\hline
\end{tabular}

TABEL III

Prosentase ReKapitulasi LETAK KeSALAHAN BERDASARKAN FoKUS PENELITIAN

\begin{tabular}{ccccc}
\hline \multirow{2}{*}{ No Soal } & KK & \multicolumn{2}{c}{ Letak Kesalahan } \\
& KO & KF & KP \\
\hline 1 & $16,67 \%$ & $50 \%$ & $0 \%$ & $0 \%$ \\
2 & $16,67 \%$ & $16,67 \%$ & $0 \%$ & $0 \%$ \\
3 & $0 \%$ & $16,67 \%$ & $33,33 \%$ & $16,67 \%$ \\
4 & $50 \%$ & $33,33 \%$ & $0 \%$ & $16,67 \%$ \\
5 & $0 \%$ & $50 \%$ & $0 \%$ & $16,67 \%$ \\
\hline
\end{tabular}

Keterangan.

$\mathrm{KK}=$ Kesalahan konsep

$\mathrm{KO}=$ Kesalahan operasi

$\mathrm{KF}=$ Kesalahan faktual

$\mathrm{KP}=$ Kesalahan prosedur

Berdasarkan tabel I dan II di atas dapat dikemukakan letak dan prosentase kesalahan yang dilakukan sebagai berikut.

1. Pada soal nomor 1, jenis kesalahan yang dilakukan mahasiswa adalah kesalahan konsep sebesar 16,67\% dan kesalahan operasi sebesar $50 \%$. Seorang mahasiswa melakukan kesalahan konsep karena tidak mengusai sepenuhnya materi tentang turunan parsial dua peubah atau lebih, sedangkan sebanyak 3 mahasiswa melakukan kesalahan operasi bilangan karena ketidaktelitian dalam pengoperasian bilangan;

2. Pada soal nomor 2, jenis kesalahan yang dilakukan oleh mahasiswa adalah kesalahan konsep dengan prosentase $16,67 \%$ dan kesalahan operasi sebesar $16,67 \%$. Seorang mahasiswa melakukan kesalahan konsep karena tidak mengusai secara baik materi tentang turang berarah, sedangkan 1 mahasiswa melakukan kesalahan operasi bilangan karena ketidaktelitian dalam pengoperasian bilangan;

3. Pada soal nomor 3, letak kesalahan yang dilakukan oleh mahasiswa adalah kesalahan operasi $16,67 \%$, kesalahan faktual 33,33\% dan kesalahan prosedur $16,67 \%$. Seorang mahasiswa melakukan kesalahan operasi bilangan karena ketidaktelitian dalam pengoperasian bilangan, 3 mahasiswa melakukan kesalahan faktual karena tidak memahami soal lagrange multipliers dan 1 mahasiswa melakukan kesalahan prosedur yang diindikasikan karena melakukan contekan;

4. Pada soal nomor 4, mahasiswa melakukan kesalahan konsep sebesar 50\%, kesalahan operasi sebesar 33,33\% dan kesalahan prosedur $16,67 \%$. Sebanyak 3 mahasiswa melakukan kesalahan konsep karena tidak menguasai sepenuhnya materi tentang sifat aditif pada integral lipat dua, sebanyak 2 mahasiswa melakukan kesalahan operasi bilangan, dan 1 mahasiswa melakukan kesalahan prosedur yang diindikasikan karena melakukan contekan;

5. Pada soal nomor 5, kesalahan yang dilakukan mahasiswa adalah kesalahan operasi $50 \%$, dan kesalahan prosedur $16,67 \%$. Sebanyak 3 mahasiswa melakukan kesalahan operasi bilangan dan 1 mahasiswa melakukan kesalahan 


\section{- - - Jurnal Pendidikan Matematika Indonesia \\ Volum 3 Nomor 1 bulan Maret 2018. Page 7-14 \\ p-ISSN: 2477-5967 e-ISSN: 2477-8443}

prosedur yang diindikasikan karena tidak menguasai dengan baik materi tentang penerapan integral lipat untuk menentukan luas suatu bidang arsiran dan melakukan contekan.

Berikut adalah contoh hasil jawaban mahasiswa dalam mengerjakan soal Kalkulus Peubah Banyak.

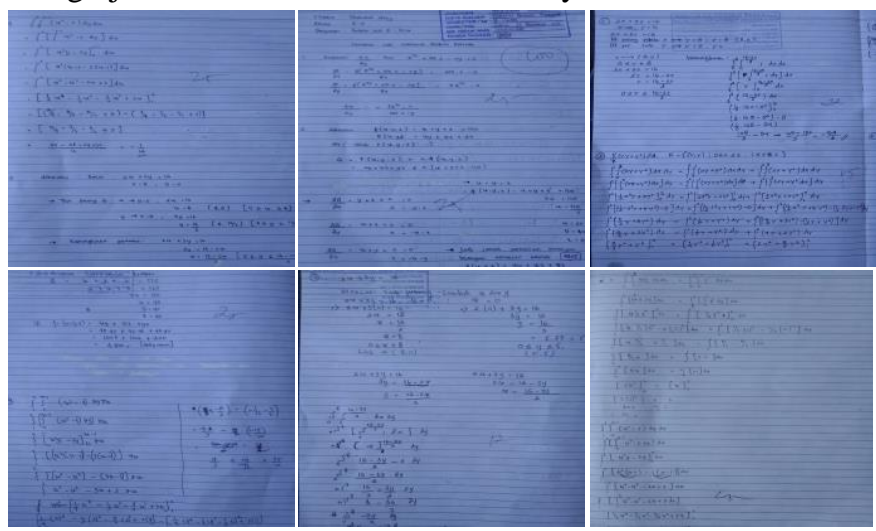

Gambar 1. Hasil Jawaban Mahasiswa

B. Solusi alternatif yang dapat diberikan untuk mengatasi kesalahan yang dilakukan mahasiswa dalam menyelesaikan soal.

1. Subyek penelitian 1 (AK, NIM. 160103002)

Pada soal nomor 1, AK tidak dapat menyelesaikan jawaban. AK tidak memiliki pemahaman yang komprehensif dalam menjawab soal tentang turunan parsial fungsi dua peubah atau lebih. Untuk mengatasi permasalahan tersebut maka AK harus belajar lagi konsep tentang turunan parsial fungsi dua peubah atau lebih. Soal nomor 2, AK melakukan kesalahan operasi hitung bilangan ketika mengoperasikan bilangan ke rumus turunan berarah. Kesalahan tersebut dapat diatasi dengan memperbanyak latihan soal tentang operasi bilangan atau meningkatkan ketelitian dalam menjawab. Pada soal nomor 3, AK tidak memahami pertanyaan sehingga tidak mampu menjawab dengan baik. Solusi untuk permasalahan ini adalah dengan belajar lagi materi tersebut secara maksimal. Pada soal nomor 4, AK melakukan kesalahan pada penentuan nilai batas atas integral yang berakibat terjadinya kesalahan pada seluruh jawaban di bawahnya padahal operasi yang dilakukan benar. Untuk mengatasi hal ini, maka mahasiswa tersebut harus memahami terlebih dahulu bagaimana cara memecah batas agar memenuhi syarat sifat aditif. Pada soal nomor 5, AK melakukan kesalahan, yaitu tidak runtutnya jawaban yang diindikasikan sebagai hasil dari contekan. Permasalahan tersebut dapat diatasi dengan peningkatan pemahaman terhadap materi tentang penentuan luas bidang arsiran menggunakan intergral lipat secara baik.

2. Subyek penelitian 2 (MIH, NIM. 160103026)

Pada soal nomor 1, secara umum MIH sudah memahami apa yang ditanyakan serta mampu menyelesaikannya, namun pada bagian kesimpulan akhir MIH melakukan kesalahan operasi yang berakibat pada kesalahan pada jawaban akhirnya. Kesalahan tersebut dapat diatasi dengan memperbanyak latihan soal tentang operasi bilangan atau meningkatkan ketelitian dalam menjawab. Pada soal nomor 2, MIH tidak menguasai secara baik soal turunan berarah yang diberikan. Solusi pemecahan masalah tersebut adalah dengan memahami kembali materi tentang turunan berarah. Untuk soal nomor 3, MIH tidak dapat menuliskan jawaban karena ketidakmampuan memahami pertanyaan. Kasus kesalahan tersebut hanya dapat dicari solusinya dengan belajar lebih serius lagi tentang materi tersebut. Pada soal nomor 4, MIH terindikasi melakukan contekan karena struktur jawaban tidak sistematis dan hanya benar pada saat menentukan batasan integral saja. Prosedur pengerjaan soal yang tidak benar dapat diatasi dengan belajar atau memperbanyak latihan soal tentang integral lipat dua menggunakan sifat aditif bilangan. Pada soal nomor 5, MIH melakukan kesalahan operasi bilangan sehingga berakibat kesalahan dalam menjawab pertanyaan. Kesalahan tersebut dapat diatasi dengan memperbanyak latihan soal tentang operasi bilangan atau meningkatkan ketelitian dalam menjawab.

\section{Subyek penelitian 3 (NA, NIM. 160103011)}

Pada soal nomor 1, NA memahami pertanyaan dan mampu merumuskan jawaban dengan baik, namun pada bagian akhir NA melakukan kesalahan operasi bilangan sehingga jawaban akhir tidak tepat. Kesalahan tersebut dapat diatasi dengan memperbanyak latihan soal tentang operasi bilangan atau meningkatkan ketelitian dalam menjawab soal turunan parsial fungsi dua peubah atau lebih. Pada soal nomor 3, NA kembali melakukan kesalahan hitung bilangan. Kesalahan tersebut dapat diatasi dengan memperbanyak latihan soal tentang operasi bilangan atau meningkatkan ketelitian dalam menjawab soal lagrange multipliers. Pada soal nomor 4, NA melakukan kesalahan ketika mensubstitusikan batas integral ke fungsi integral, maka NA perlu belajar lagi tentang bagaimana cara mensubstitusi bilangan ke suatu fungsi yang ditentukan. Pada soal nomor 5, NA kembali melakukan kesalahan operasi pada bagian akhir (seperti soal nomor 1 dan 3) akibat ketidaktelitian yang bersangkutan. Dengan demikian NA harus memperbanyak latihan soal tentang operasi bilangan atau meningkatkan ketelitian dalam menjawab soal penerapan integral untuk menentukan luas bidang arsiran.

\section{Subyek penelitian 4 (TR, NIM. 160103006)}

Pada soal nomor 1, TR memahami pertanyaan dan mampu merumuskan jawaban dengan baik, namun pada bagian akhir TR melakukan kesalahan operasi sehingga jawaban akhir tidak tepat. Kesalahan tersebut dapat diatasi dengan memperbanyak latihan soal tentang operasi bilangan atau meningkatkan ketelitian dalam menjawab soal turunan parsial fungsi dua peubah atau lebih. Pada soal nomor 3, TR terindikasi melakukan contekan karena struktur jawaban tidak sistematis dan hanya benar pada saat menentukan menghitung taksiran nilai diferensial. Prosedur pengerjaan soal yang tidak benar dapat diatasi dengan belajar atau memperbanyak latihan soal tentang taksiran nilai diferensial kasus lagrange multipliers. Pada soal nomor 4, NA melakukan kesalahan ketika mensubstitusikan batas integral ke fungsi integral. Untuk mengatasi permasalahan tersebut maka TR harus belajar lagi cara mensubstitusikan nilai batas 
ke fungsi integralnya. Pada soal nomor 5, NA kembali melakukan kesalahan operasi pada bagian akhir akibat ketidaktelitian yang bersangkutan. Kesalahan tersebut dapat diatasi dengan memperbanyak latihan soal tentang operasi bilangan atau meningkatkan ketelitian dalam menjawab.

5. Subyek penelitian 5 (NMK, NIM. 160103012)

Pada soal nomor 4, NMK melakukan kesalahan operasi hitung bilangan. Untuk mengatasi hal tersebut, maka NMK harus memperbanyak latihan soal tentang operasi bilangan atau meningkatkan ketelitian dalam menjawab.

6. Subyek penelitian 6 (AM, NIM. 160103030)

Pada soal nomor 4, AM melakukan kesalahan operasi hitung bilangan. solusi untuk permasalahan tersebut adalah dengan memperbanyak latihan soal tentang operasi bilangan atau meningkatkan ketelitian dalam menjawab.

TABEL IIIII

REKAPITULASI Kesalahan BERDASARKAN FoKUS PENELITIAN

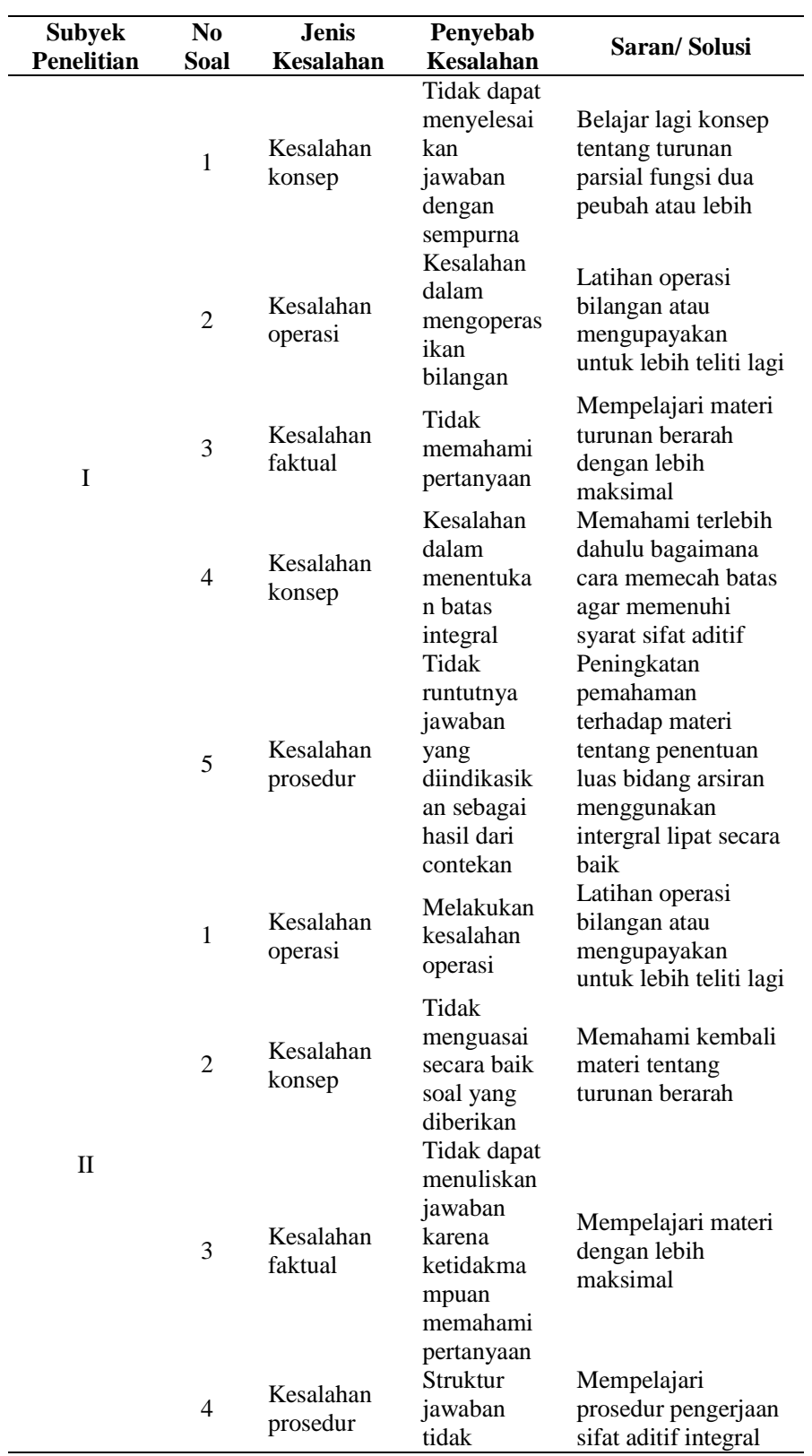

sistematis

dan hanya

benar pada

saat

menentuka

n batasan

integral

saja

Melakukan

kesalahan

operasi

bilangan

operasi

Melakukan

kesalahan

operasi

bilangan

operasi

Melakukan

kesalahan

Kesalahan

hitung

bilangan

III

Melakukan

kesalahan

ketika

Kesalahan mensubstitu

sikan batas

integral ke

fungsi

integral

Melakukan

kesalahan

operasi

pada bagian

akhir

Melakukan

kesalahan

Kesalahan operasi

operasi

pada bagian

akhir

Kesalahan

dalam

mengoperas

ikan

bilangan

IV

Kesalahan

dalam

4 Kesalahan mensubstitu

konsep

sikan batas

integral

Kesalahan

dalam

Kesalahan

mengoperas

ikan

bilangan

Melakukan

kesalahan

operasi

hitung

bilangan lipat dua

Memperbanyak

latihan soal tentang

operasi bilangan

atau meningkatkan

ketelitian dalam

menjawab

Memperbanyak

latihan soal tentang

operasi bilangan

atau meningkatkan

ketelitian dalam menjawab

Memperbanyak

latihan soal tentang

operasi bilangan

atau meningkatkan

ketelitian dalam

menjawab

Belajar lagi tentang

bagaimana cara

mensubstitusi

bilangan ke suatu

fungsi

Memperbanyak

latihan soal tentang

operasi bilangan

atau meningkatkan

ketelitian dalam

menjawab

Memperbanyak

latihan soal tentang

operasi bilangan

atau meningkatkan

ketelitian dalam

menjawab

Memperbanyak

latihan soal tentang

operasi bilangan

atau meningkatkan

ketelitian dalam

menjawab

Belajar lagi tentang

bagaimana cara

mensubstitusi

bilangan ke suatu

fungsi

Memperbanyak

latihan soal tentang

operasi bilangan

atau meningkatkan

ketelitian dalam

menjawab

Memperbanyak

latihan soal tentang

operasi bilangan

atau meningkatkan

ketelitian dalam

menjawab 


\begin{tabular}{cclll}
\hline VI & & & $\begin{array}{l}\text { Melakukan } \\
\text { kesalahan } \\
\text { operasi } \\
\text { kitung } \\
\text { kilangan }\end{array}$ & $\begin{array}{l}\text { Memperbanyak } \\
\text { latihan soal tentang } \\
\text { operasi bilangan } \\
\text { atau meningkatkan } \\
\text { ketelitian dalam } \\
\text { menjawab }\end{array}$ \\
\hline
\end{tabular}

Kesalahan yang merepresentasikan kesulitan mahasiswa dalam menjawab pertanyaan Kalkulus Peubah Banyak juga terlihat secara langsung melalui respon mahasiswa dari hasil wawancara sebagai berikut.

a. Hasil wawancara tentang jawaban soal nomor 1

P : "menurut kalian, apakah soal nomor 1 itu sulit?"

AK : "sebenarnya mudah, pak. Tapi saya lupa bagaimana turunan eksponen yang terhadap ynya"

MIH : "kalau saya kurang teliti ja sih, Pak. Seharusnya nilai pangkat $3 y$ itu saya kalikan dengan koefisien e3y ya"

P : (kepada AK) "seharusnya jangan dihafal, kita hanya memperhatikan pangkat eksponennya saja. Kita tinggal turunkan dengan mengalikan koefisiennya. Kalau suku yang lain biasa saja kan cara menurunkannya"

AK : "iya pak. Cuma tadi bingung gimana caranya yang turunan eksponen"

AM : "soal itu sebenarnya hampir sama dengan contoh yang pernah kita bahas kan pak. Jadi kalau saya, hanya memahami soal yang kemarin itu"

P : :iya benar. Berarti permasalahannya karena yang kemarin itu kalian belum sepenuhnya mengerti penyelesaian turunan parsial fungsi eksponen"

MIH : "iya Pak, hehe"

b. Hasil wawancara tentang jawaban soal nomor 2

$\mathrm{P} \quad$ : "apa permasalahan yang kalian temukan ketika mengerjakan soal nomor 2?"

NMK : "tidak ada pak"

AM : "iya, gampang koq pak"

MIH : "saya lupa rumus fungsi G nya pak"

$P \quad$ : "notasi fungsi itu tidak harus $G$, tapi kalau ingin mengikuti yang kemarin kita pelajari bersama juga boleh. Yang dingat-ingat disini adalah gimana aturan turunan berarahnya saja"

$P \quad$ : "(kepada AK) mengapa turunan $G$ terhadap $x$ nya begitu hasilnya?"

AK : "iya salah pak, harusnya $-y-z$ ya"

c. Hasil wawancara tentang jawaban soal nomor 3

$\mathrm{P} \quad$ : "lagrange multipliers susah gak?"

AK : "susah, pak. Saya tidak ingat sama sekali, ngeblank saya"

TR : "iya pak susah. Saya juga gak segitu ingat gimana cara mengerjakannya"

P : "kan cuma berbeda fungsinya dari contoh yang dulu kita pelajari?"

TR : "iya pak, kurang belajar kitanya hehe"

P : : "(kepada NMK) kalau kamu gimana?"
NMK : "gampang pak. Mungkin teman-teman susahnya karena disitu kan banyak rumus yang harus kita pahami ya"

AM : "iya pak. Saya juga kemarin sempat lupa hehe"

d. Hasil wawancara tentang jawaban soal nomor 4

$\mathrm{P} \quad$ : "mengapa banyak yang salah mengerjakan soal nomor 4? Dimana letak sulitnya?"

MIH : "saya salah subsitusi batas integralnya pak"

NA : "saya tidak memecah batas integralnya"

NMK : "sudah saya pecah sih batas integralnya. Tapi kurang teliti ketika mengalikan pak"

P : "iya. Karena integral menggunakan sifat aditif, kuncinya memang harus memecah batas integral menjadi beberapa batas. Jadi harus lebih teliti lagi"

AK : "iya pak"

e. Hasil wawancara tentang jawaban soal nomor 5

P : "untuk soal nomor 5, dimana letak kesulitnya?"

AK : "saya lupa caranya pak, cuma ingat sampai batas integral bidang yang diarsir saja"

NA : "kurang teliti saja di operasi integralnya pak"

$\mathrm{P}$ : "sebenarnya tidak ada masalah dengan konsepnya ya, hanya kurang teliti dalam oeprasinya saja berarti. (kepada AK) harus belajar lebih giat lagi ya, bisa juga tanya ke temantemannya bagaimana caranya"

AK : "iya pak"

Berdasarkan hasil wawancara yang telah dilakukan dengan subyek penelitian, diperoleh informasi sebagai berikut.

a. Dari aspek materi perkuliahan, sebagian besar mahasiswa masih mengalami kesulitan ketika menentukan nilai turunan fungsi eksponensial, menentukan rumus turunan berarah, melakukan prosedur penyelesaian lagrange multipliers, melakukan pemecahan batas integral pada sifat aditif integral lipat dua dan menentukan rumus fungsi bidang arsiran. Kasus yang dialami mahasiswa beberapa diantaranya berkaitan dengan operasi bilangan, pemahaman materi yang tidak komprhensif, ketidaktahuan dalam menjawab pertanyaan dan kesalahan prosedur mengerjakan soal;

b. Dari aspek lingkungan, ruang perkuliahan serta fasilitas pendukung, seperti koleksi buku referensi yang dimiliki perpustakaan (baik perpustakaan universitas maupun program studi) dinilai kurang lengkap bagi pemenuhan kebutuhan pengetahuan tambahan bagi mahasiswa. Di samping itu, suasana tempat belajar (ruang perkuliahan) juga dinilai kurang representatif bagi proses pembelajaran yang efektif dan menyenangkan. Beberapa mahasiswa bahkan mengaku gerah (panas) dalam ruangan;

c. Dari aspek mahasiswa, mahasiswa cenderung memiliki pola belajar yang kurang bagus. Rata-rata mahasiswa hanya belajar ketika ujian akan dilangsungkan. Dalam proses perkuliahan, hanya sebagian kecil mahasiswa 
yang terlihat aktif/berkontribusi dalam pembelajaran, baik bertanya maupun memberikan jawaban atas pertanyaan dosen, sedangkan sebagian besar mahasiswa yang lain hanya mendengarkan penjelasan saja tanpa ada proses menggali pemahamannya secara lebih maksimal lagi; dan

d. Dari aspek dosen, metode/model pengajaran yang kurang disukai mahasiswa bisa menyebabkan kurangnya motivasi mahasiswa dalam belajar. Beberapa mahasiswa bahkan menyampaikan permintaan metode pembelajaran ketika perkuliahan berlangsung. Hal ini menunjukkan respon mahasiswa yang menginginkan adanya inovasi/rotasi metode/model pembelajaran agar lebih menarik lagi.

\section{KESIMPULAN}

Berdasarkan hasil penelitian serta pembahasan di atas, maka dapat disimpulkan letak dan jenis kesalahan mahasiswa, faktor serta solusi yang perlu dilakukan untuk mengatasi kesalahan yang dilakukan sebagai berikut.

1. Letak dan jenis kesalahan mahasiswa dalam menyelesaikan soal Kalkulus Peubah Banyak, yaitu:
a. Kesalahan Konsep (KK);
b. Kesalahan Operasi (KO);
c. Kesalahan Faktual (KF); dan
d. Kesalahan Prosedur (KP).

2. Faktor penyebab mahasiswa melakukan kesalahan dalam menyelesaikan soal Kalkulus Peubah Banyak adalah sebagai berikut.

a. Kesalahan konsep dikarenakan mahasiswa melakukan kesalahan karena tidak memahami materi soal yang diujikan secara baik;

b. Kesalahan operasi dikarenakan mahasiswa melakukan kesalahan dalam mengoperasikan bilangan;

c. Kesalahan faktual dikarenakan mahasiswa tidak dapat menjawab karena tidak memiliki kemampuan dalam memahami soal; dan

d. Kesalahan prosedur dikarenakan mahasiswa melakukan kesalahan dalam sistematika penyelesaian.

3. Solusi alternatif untuk mengatasi kesalahan yang dilakukan mahasiswa dalam menyelesaiakan soal Kalkulus Peubah Banyak adalah sebagai berikut.

a. Dalam proses pembelajaran, dosen sebaiknya menekankan pada pemahaman konsep agar materi yang dipelajari diterima secara utuh;

b. Dalam menjawab soal, dosen menekankan ketelitian kepada mahasiswa sebelum menjawab soal mahsiswa sebaiknya teliti dalam membaca dan memahami soal dengan cara membaca berulang-ulang agar jawaban sesuai dengan apa yang diinginkan;

c. Dalam memecahkan soal, mahasiswa perlu melalui beberapa tahapan, yaitu:

1) Memahami masalah atau soal;

2) Menyusun rencana atau langkah yang akan dilakukan;

3) Melaksanakan rencana; dan
4) Menguji kembali atau memeriksa kembali.

\section{DAFTAR PUSTAKA}

Arifin, Zaenal. 2008. Metodologi Penelitian Pendidikan.Surabaya: Lentera Cendekia

Djamarah, Syaiful Bahri. 1994. Prestasi Belajar dan Kompetensi Guru. Surabaya: Usaha Nasional

Hamid, Darmadi. 2011. Metode Penelitian Pendidikan. Bandung: Alfabeta

Hudojo, Herman. 2011. Strategi Mengajar Belajar Matematika. Malang: IKIP Malang Press

Margono, S. 1997. Metodologi Penelitian Pendidikan. Jakarta: Rineka Cipta

Monks, F. J. dkk. 2004. Psikologi Perkembangan. Yogyakarta: Gadjah Mada University Press

Nasution. 2005. Berbagai Pendekatan dalam Proses Belajar \& Mengajar. Jakarta: Bumi Aksara

Sagala, Syaiful. 2007. Konsep Dan Makna Pembelajaran. Bandung: Alfabeta

Simanjutak. 1993. Metode Mengajar Matematika. Jakarta: Rineka Cipta

Sugiyono. 2012. Metode Penelitian Kuantitatif, Kualitatif dan R\&D. Bandung: Alfabet

Suharsimi, Arikunto. 2006. Prosedur Penelitian Suatu Pendekatan Praktik. Jakarta: Rineka Cipta

Slameto. 2010. Belajar \& Faktor-Faktor Yang Mempengaruhi. Jakarta: Rineka Cipta

Suharsimi, Arikunto. 2010. Prosedur Penelitian Suatu Pendekatan Praktik. Jakarta: Rineka Cipta. 